\title{
VOLTAMMETRIC DETERMINATION OF RESVERATROL USING POLY(L-PHENYLALANINE)-MODIFIED GOLD ELECTRODE
}

\author{
Öznur Güngör ${ }^{1}$, Chedia Ben Ali Hassine ${ }^{2}$, Muammer Burç ${ }^{1}$, Serap Titretir Duran ${ }^{1 *}$ \\ ${ }^{1}$ Chemistry Department, Arts and Sciences Faculty, İnönü University, 44280, Malatya, Turkey \\ ${ }^{2}$ Electrical and Electronics Engineering Department, Engineering Faculty, Özyeğin University, \\ Istanbul, Turkey \\ serap.titretir@inonu.edu.tr
}

\begin{abstract}
In this study, we investigated the electrochemical modification of a gold electrode using poly $(\mathrm{L}-$ phenylalanine) and its applicability for the quantification of resveratrol (RESV). The gold electrode was modified with L-phenylalanine employing cyclic voltammetry (CV) in aqueous solution. The detection of RESV with the modified electrode was investigated by square wave voltammetry (SWV) in a phosphate buffer solution (PBS) $(\mathrm{pH}=1.2)$. The analytical calibration curve for RESV showed a linear response with concentration in the oxidation peak current range from 50 to $1000 \mu \mathrm{M}$, with a limit of detection (LOD) of $35.16 \mu \mathrm{M}$ and limit of quantitation (LOQ) of $105.5 \mu \mathrm{M}$. The application of the prepared electrochemical sensor was carried out with a standard addition method in red wine samples.
\end{abstract}

Keywords: L-phenylalanine; resveratrol; electropolymerization; square wave voltammetry

\section{ВОЛТАМЕТРИСКО ОПРЕДЕЛУВАЫЕ НА РЕСВЕРАТРОЛ СО ЕЛЕКТРОДА ОД ЗЛАТО МОДИФИЦИРАНА СО ПРИМЕНА НА ПОЛИ(Ц-ФЕНИЛАЛАНИН)}

Во оваа студија ја испитавме електрохемиската модификација на електрода од злато со примена на поли(L-фенилаланин) и нејзината применливост за квантификација на ресвератрол (RESV). Електродата од злато беше модифицирана со L-фенилаланин со користење на циклична волтаметрија (CV) во водна средина. Детекцијата на RESV со модифицираната електрода беше испитана со квадратно-бранова волтаметрија (SWV) во раствор на фосфатен пуфер (PBS) (pH = 1,2). Аналитичката калибрациона крива за RESV покажа линеарен одговор со концентрација на оксидацискиот пик во областа од 50 до $1000 \mu \mathrm{M}$, со граници на детекција (LOD) од 35,16 $\mu \mathrm{M}$ и граници на квантификација од (LOQ) од $105,5 \mu \mathrm{M}$. Применливоста на подготвениот електрохемиски сензор беше испитана со методот на стандардни адиции на примероци од црвено вино.

Клучни зборови: L-фенилаланин; ресвератрол; електрополимеризација; квадратно-бранова волтаметрија.

\section{INTRODUCTION}

RESV (3,5,4'-trihydroxystilben) is a natural polyphenolic compound [1] with a stilbene derivative [2] (Scheme 1). Polyphenols, as antioxidants, have the ability to remove free radicals formed in the human body for various reasons. They are also known to reduce the risk of cardiovascular disease and cancer due to their reduction of oxidative stress [3]. RESV has various anti-inflammatory, anti-proliferative, anti-tumoral, biochemical, and physiological effects [4].

In addition, RESV is an effective antimicrobial and antifungal compound produced by plants 
against microbial, fungal, and physical stimuli [5], and it is present in significant amounts in grapes, berries, peanuts and red wine.

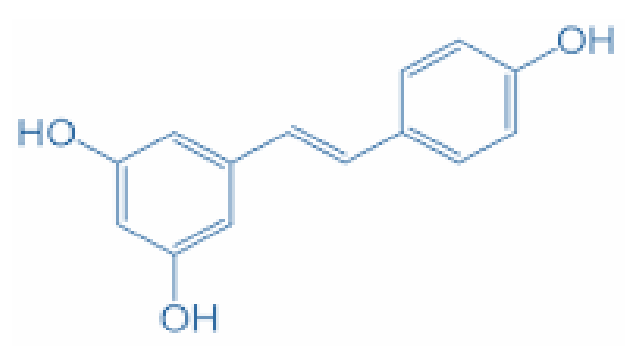

Scheme 1. Chemical structure of trans-RESV

RESV recently attracted researchers' attention due to its nutraceutical and therapeutic potential for many diseases. For example, it could play a potential protective role against cardiovascular diseases [6]. RESV has several biological and pharmacological effects including anticancer, antiinflammatory, cardio-protective and antioxidant activities [7, 8]. Also, its beneficial effects on diseases related to age, such as type two diabetes, cardiovascular diseases, cancer, and neurological diseases, are of great interest [5].

There are determination methods for RESV in literature, such as chromatography [9] or ultra violet (UV) analysis. Nevertheless, these methods are expensive and time-consuming. In general, electrochemical methods have been used as alternatives to detect a large number of important analytes, such as food [10], environmental [11], and pharmaceutical [12, 13] components. However, electrochemical methods could be considered promising procedures for the evaluation of RESV properties [14]. Electrochemical methods provide a rapid response, high sensitivity, and low detection limit [15, 16]. RESV, as a phenolic compound, shows electrochemical activity and can be analyzed by electrochemical methods [17]. Some electrochemical sensors for RESV have been reported in literature already [18]. Hitherto, researchers have worked on the electrochemical oxidation mechanism and electrochemical sensing of RESV with unmodified electrodes, such as the glassy carbon electrode (GCE) [19, 20], carbon paste electrode (CPE) [21], and graphite electrode [17, 19]. Only some articles reported the use of modified electrodes [14]. In this work, a gold electrode was modified by poly(L-phenylalanine) using $\mathrm{CV}$ in aqueous solution containing $0.1 \mathrm{M}$ potassium nitrate $\left(\mathrm{KNO}_{3}\right)$. Electrochemical modification of the gold electrode by poly(L-phenylalanine) was stud- ied [22, 23]. After the gold electrode was modified, its sensitivity towards RESV was tested by SWV. The aim of this work is the development of a method for RESV detection using an electrochemically modified gold electrode. The novelty of this work is the high sensitivity provided by the electrochemical RESV sensor using a simple modified gold electrode.

\section{MATERIALS AND METHODS}

\subsection{Materials}

L-phenylalanine, potassium ferricyanide $\left(\mathrm{K}_{4}\left[\mathrm{Fe}(\mathrm{CN})_{6}\right]\right)$, potassium dihydrogen phosphate $\left(\mathrm{KH}_{2} \mathrm{PO}_{4}\right)$, sodium monohydrogen phosphate $\left(\mathrm{Na}_{2} \mathrm{HPO}_{4}\right), \mathrm{KNO}_{3}$, nitric acid $\left(\mathrm{HNO}_{3}\right)$, and RESV were purchased from Sigma-Aldrich. Sodium acetate $\left(\mathrm{CH}_{3} \mathrm{COONa}\right)$, acetic acid $\left(\mathrm{CH}_{3} \mathrm{COO}\right)$, sodium perchlorate $\left(\mathrm{NaClO}_{4}\right)$, potassium chloride $(\mathrm{KCl})$, phosphoric acid $\left(\mathrm{H}_{3} \mathrm{PO}_{4}\right)$, boric acid $\left(\mathrm{H}_{3} \mathrm{BO}_{3}\right)$, hydrochloric acid $(\mathrm{HCl})$, and sodium hydroxide $(\mathrm{NaOH})$ were purchased from Merck. All aqueous solutions were prepared with ultrapure water.

\subsection{Instrumentation}

A three-electrode cell system was employed in all electrochemical experiments. A platinum wire was used as a counter electrode, and gold electrodes with geometric areas of $0.07 \mathrm{~cm}^{2}$ were used as working electrodes. The reference electrode was $\mathrm{Ag} / \mathrm{AgCl}$ in saturated $\mathrm{NaCl}$ solution $(\mathrm{Ag} / \mathrm{AgCl} / \mathrm{sat}$. $\mathrm{NaCl}))$. The electrochemical experiments were done using a potentiostat (Vertex one) controlled by computer software (Ivium soft) for data analysis. Square wave measurements used for RESV detection were performed after $60 \mathrm{~s}$ of a pre-concentration step with an accumulation potential of $-0.5 \mathrm{~V}$ under stirring. After the accumulation step, square wave measurements were recorded from -0.5 to $1 \mathrm{~V}$ with an amplitude of $50 \mathrm{mV}$ and a frequency of $70 \mathrm{~Hz}$ in the presence of PBS $0.1 \mathrm{M}(\mathrm{pH}=1.2)$ containing $5 \mu \mathrm{l}$ of Tween 20 . All glassware and electrochemical cells were kept in 6 $\mathrm{M} \mathrm{HNO}_{3}$ overnight to remove impurities, and all electrochemical measurements were carried out at room temperature.

\subsection{Electrode modification}

The gold electrode surface was hand polished with a $0.05 \mu \mathrm{m}$ alumina-water slurry using a polishing cloth. The polished electrode was rinsed 
with ultrapure water, sonicated in ultrapure water for $3 \mathrm{~min}$, and, finally, rinsed again with ultrapure water to remove impurities on the electrode surface. Then, the electrode was modified using Lphenylalanine $(100 \mathrm{mM})$ by six reversible potential cycles between +1.5 and $+0 \mathrm{~V}$ in an aqueous solution containing $100 \mathrm{mM} \mathrm{KNO}$ at a scan rate of 80 $\mathrm{mV} \cdot \mathrm{s}^{-1}$. After the polymerization step, the surface of the modified electrode was washed with ultrapure water to remove surface impurities.

\section{RESULTS AND DISCUSSION}

\subsection{Gold electrode modification}

The polished and cleaned gold electrode was modified by six potential cycles between +1.5 and $+0.0 \mathrm{~V}$ at a scan rate of $80 \mathrm{mV} / \mathrm{s}$. The CVs were taken on the gold electrode both in the background solution (aqueous solution containing $100 \mathrm{mM}$ $\mathrm{KNO}_{3}$; Fig. 1A) and in the background solution containing $100 \mathrm{mM}$ L-phenylalanine (Fig. 1B).

From Figure 1B, we see the polymerization of L-phenylalanine from changes in the $\mathrm{CVs}$ of Lphenylalanine during modification of the gold electrode. In the first cycle, a peak was formed on the gold electrode that could be attributed to the oxida- tion of L-phenylalanine at $1100 \mathrm{mV}$, as this peak was not observed in the voltammogram of the background electrolyte solution (Fig. 1A). With the increasing number of cycles, a continuous decrease in peak current was observed, indicating growth of the polymeric film at the gold electrode surface. According to the literature, upon the oxidation of amines on metallic electrodes, the amino group of L-phenylalanine was oxidized to a free radical and, then, covalently immobilized onto the gold electrode surface [24]. The electropolymerized L-phenylalanine film structure is shown in Scheme 2 [22].

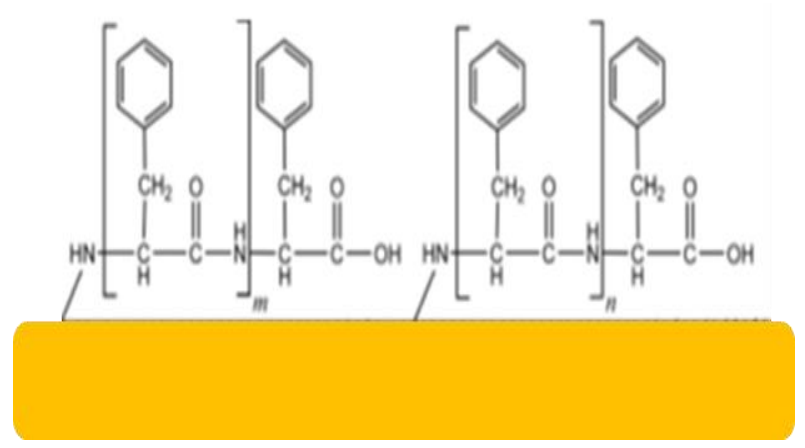

Scheme 2. Proposed structure of the poly(L-phenylalanine) film at the gold electrode surface
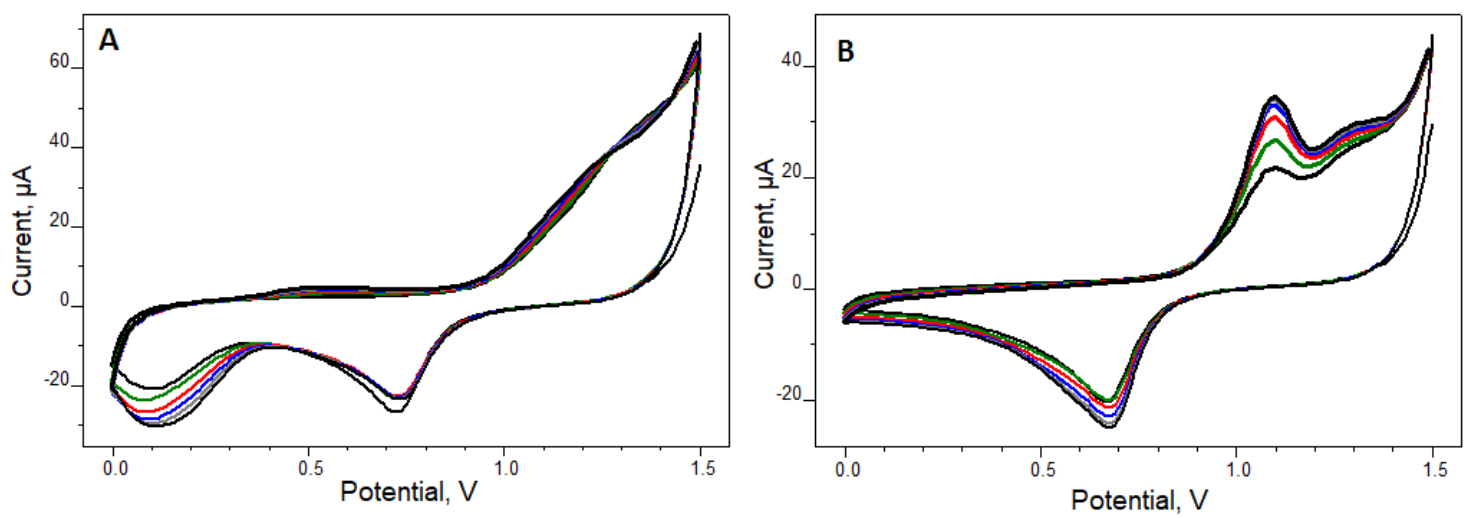

Fig. 1. CVs of the background solution (A) and electrochemical polymerization of L-phenylalanine in the background solution (B) on a gold electrode (cycle number $=6$, scan rate $=80 \mathrm{mV} / \mathrm{s} v s . \mathrm{Ag} / \mathrm{AgCl} /(\mathrm{sat} . \mathrm{NaCl})$ )

\subsubsection{Monomer concentration effect}

The monomer concentration used for poly(L-phenylalanine) film preparation plays an important role in the electrochemical properties of the deposited layer. Figure 2 shows a comparison of the RESV current responses obtained with a modified gold electrode after electropolymerization of L-phenylalanine at concentrations from 10 to $150 \mathrm{mM}$. As seen, $100 \mathrm{mM}$ of L-phenylalanine concentration gives the highest anodic peak current for RESV (Fig. 2).

The current response of RESV on the poly(L-phenylalanine)/gold electrode gradually increased as the concentration of L-phenylalanine increased from 1 to $100 \mathrm{mM}$ and, then, decreased as the L-phenylalanine concentration increased further. Therefore, a $100 \mathrm{mM}$ monomer concentration was used for subsequent experiments. 


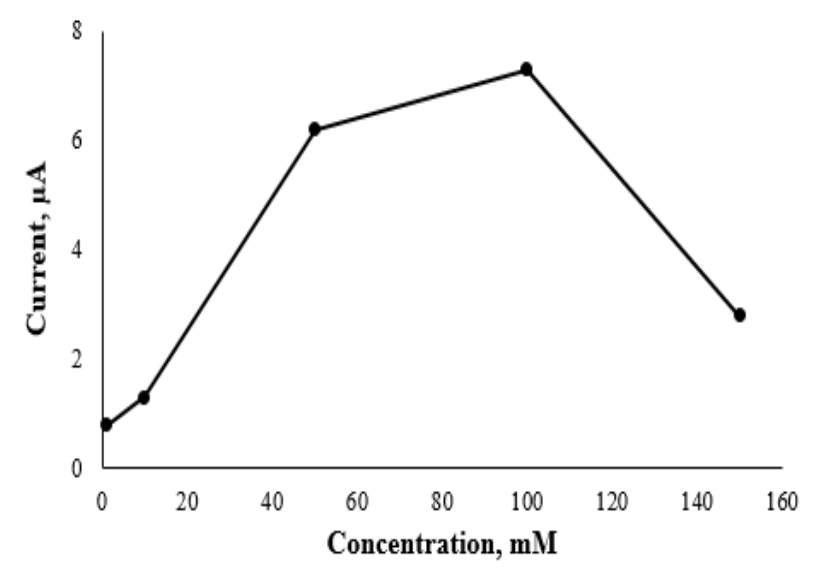

Fig. 2. Relationship between anodic current of $1 \mathrm{mM}$ RESV $v s$. monomer concentration

\subsubsection{Cycle number effect}

The cycle number effect on the anodic current response of $1 \mathrm{mM}$ RESV was tested by the SWV method, and results are shown in Figure 3. The current response of RESV on the modified electrode increased as the number of cycles increased from two to six, and then, it decreased for cycle numbers higher than six. Therefore, six cycles were used for all experiments.

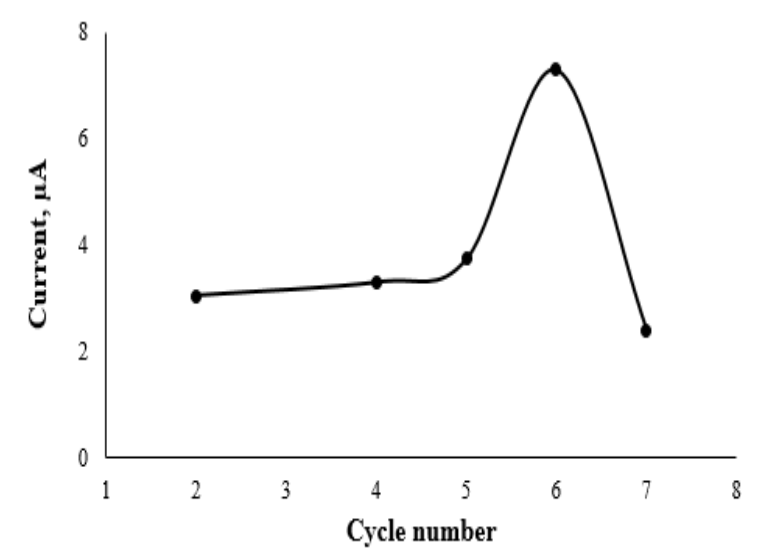

Fig. 3. Effect of cycle number on the current oxidation of RESV

\subsubsection{Gold electrode characterization}

The modified electrode's surface was characterized by $\mathrm{CV}$ at a scan rate of $100 \mathrm{mV} / \mathrm{s}$ in 6 $\mathrm{mM}$ ferrocyanide containing $1.0 \mathrm{M} \mathrm{KNO}_{3}$. Figure 4 reveals the $\mathrm{CV}$ s of the gold electrode before and after modification.

Voltammograms of the redox medium showed reversible behavior for both the bare and modified electrodes. After surface modification of the gold electrode, an increase in oxidation peak current at $310 \mathrm{mV}$ was observed from 32 to $34 \mu \mathrm{A}$.

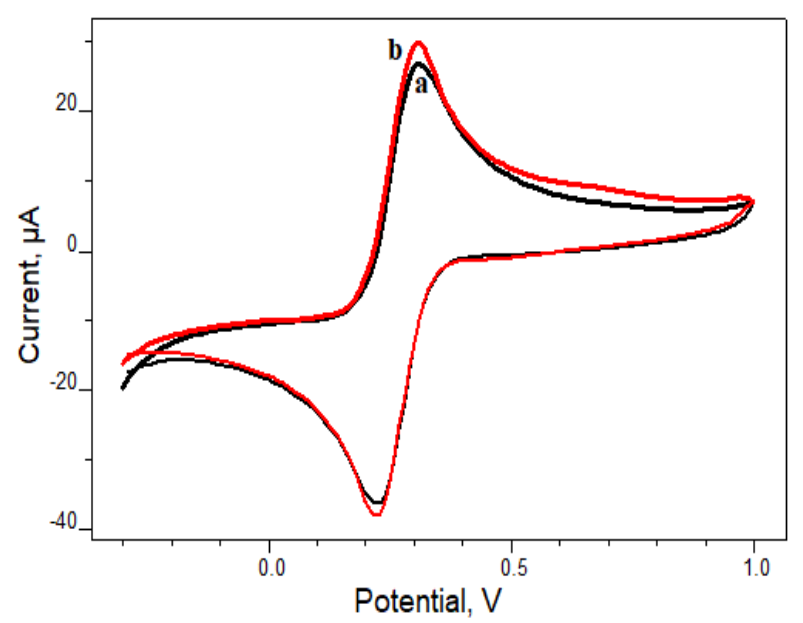

Fig. 4. CVs of $3 \mathrm{mM}$ ferrocyanide in $1.0 \mathrm{M} \mathrm{KNO}_{3}$ on a bare gold electrode (a) and on the poly(L-phenylalanine)/gold electrode (b) at a scan rate of $100 \mathrm{mV} / \mathrm{s} v s$. $\mathrm{Ag} / \mathrm{AgCl} /($ sat. $\mathrm{NaCl})$

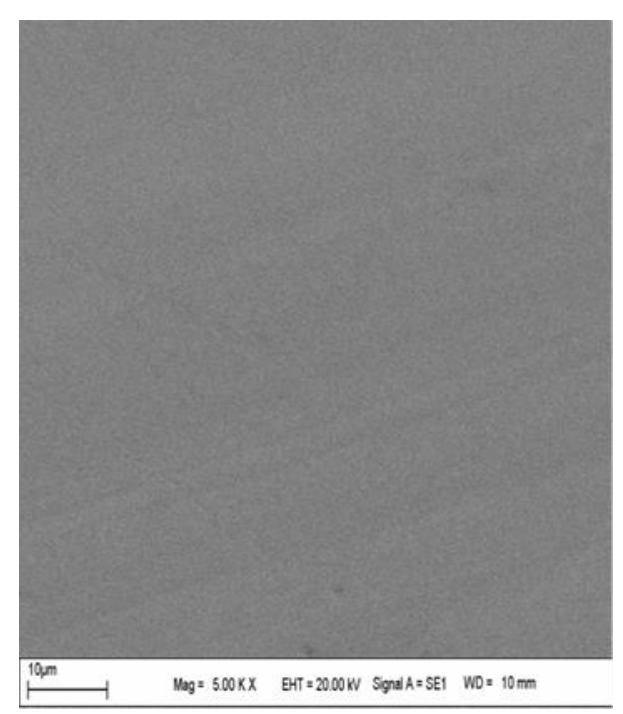

(A)

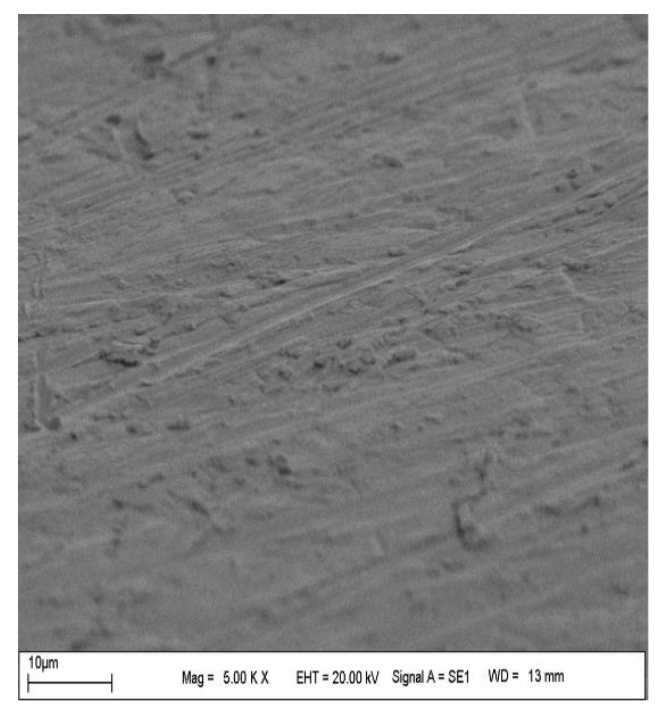

(B)

Fig. 5. SEM images of the (A) bare electrode and (B) poly(L-phenylalanine)-modified electrode 
On the other hand, the reduction peak current at $220 \mathrm{mV}$ increased from $15 \mu \mathrm{A}$ in the bare electrode to $17 \mu \mathrm{A}$ in the modified electrode. This current increase is an expected since poly $(\mathrm{L}$ phenylalanine) is a conductive polymer. To illustrate the modification of the gold electrode surface, Scanning electron microscope (SEM) images are presented in Figure 5. This figure compares the results of the SEM analysis, showing morphological changes on the gold electrode surface from electropolymerization of L-phenylalanine. The SEM of the bare gold electrode (Fig. 5A) presents a uniform surface. From Figure 5B, a uniform and compact layer is observed on the electrode surface, indicating that a poly(L-phenylalanine) film was successfully electropolymerized on the electrode surface with the formation of a well-adhered polymeric film.

\subsubsection{Electrolyte effect}

The effect of the electrolytic solution on the electro-activity of the modified electrode was studied in presence of $1 \mathrm{mM}$ RESV, and the results are summarized in Figure 6. Phosphate buffer solution (PBS) gives a higher oxidation current for RESV compared to other buffer solutions and electrolytes. Thus, PBS buffer was chosen for electrochemical detection of RESV.

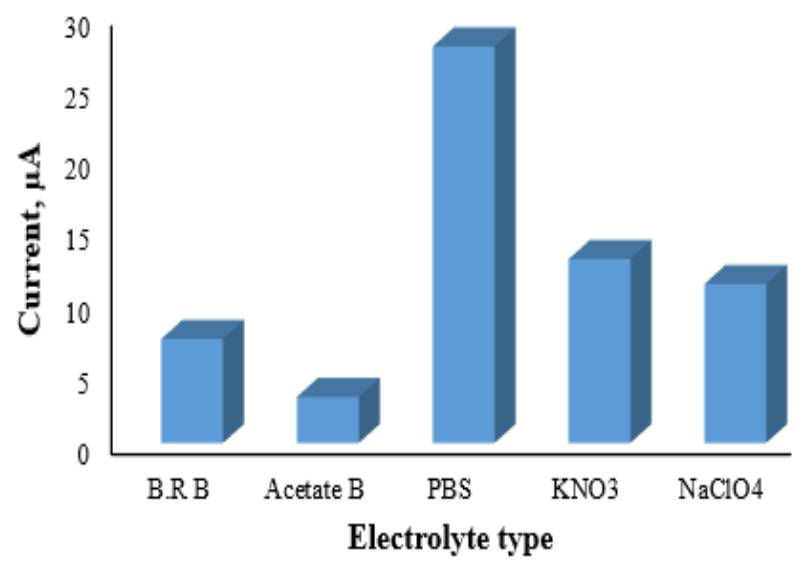

Fig. 6. Electrolyte effect for $1 \mathrm{mM}$ RESV on the poly(L-phenylalanine) gold electrode

\subsection{5. $p H$ effect}

The solution's $\mathrm{pH}$ has an important influence on the electrochemical reaction. SWV was carried out to determine the effect of $\mathrm{pH}$ on the electrochemical behavior of RESV with the poly(L-phenylalanine) gold electrode. The peak potential shifted positively upon decreasing the
$\mathrm{pH}$, from $0.7 \mathrm{~V}$ for $\mathrm{pH} 1.2$ to $0.5 \mathrm{~V}$ for $\mathrm{pH} 5$ (Fig. 7A). From Figure 7B, we observe that the peak current increased gradually and reached a maximum at $\mathrm{pH}$ 1.2. Thus, $\mathrm{pH} 1.2$ was chosen as the optimum $\mathrm{pH}$ value in the electrochemical detection of RESV. To adjust the $\mathrm{pH}$ of the phosphate buffer, $\mathrm{HCl}$ and $\mathrm{NaOH}$ were used.
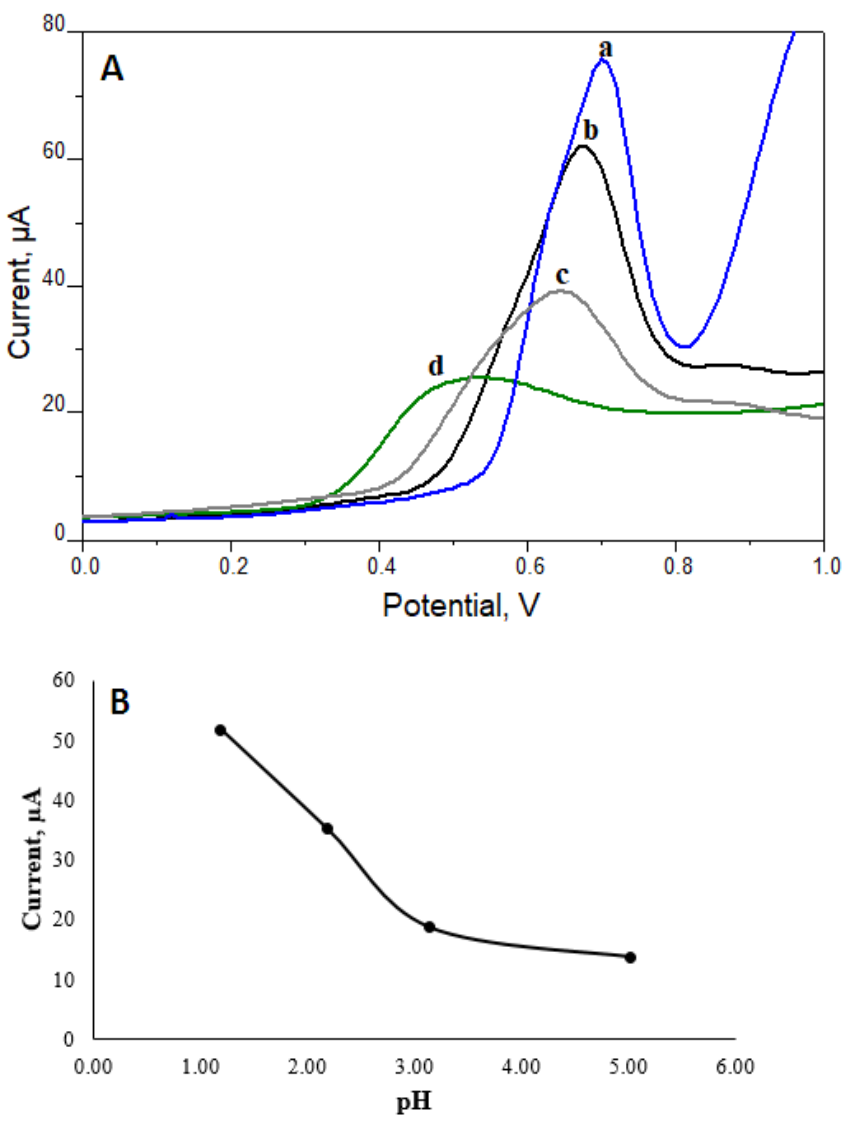

Fig. 7. (A) SWV voltammograms of $1 \mathrm{mM}$ RESV in $0.1 \mathrm{M}$ buffer solution at different $\mathrm{pH}$ values $(\mathbf{a}: 1.2, \mathbf{b}: 2.0$, c: 3.0 , d: 5.0$) v$ s. $\mathrm{Ag} / \mathrm{AgCl} /(\mathrm{sat} . \mathrm{NaCl})$. (B) Relationship between the anodic peak current and $\mathrm{pH}$ values. (Experimental conditions; SW amplitude $25 \mathrm{mV}$, step potential E step $10 \mathrm{mV}$, accumulation time $60 \mathrm{~s}$, and accumulation potential $0 \mathrm{~V}$ )

\subsubsection{Influence of $S W V$ parameters}

The effect of SWV parameters was experimentally studied. The influence of SWV conditions was presented in literature and demonstrates that SWV parameters can affect the electrode response [25-27]. SWVs were recorded for a solution containing $1 \mathrm{mM}$ of RESV using the selected conditions. Figure 8 summarizes the variation of the signal with the amplitude (A), accumulation potential $\left(E_{\text {acc }} ; \mathrm{B}\right)$, and accumulation time $\left(t_{\text {acc }} ; \mathrm{C}\right)$ in $1 \mathrm{mM}$ RESV and PBS solution $(0.1 \mathrm{M}, \mathrm{pH}=1.2)$. The amplitude's effect was studied from 10 to 100 $\mathrm{mV}$, and the highest peak current was observed at 
$50 \mathrm{mV}$, as shown in Figure 8A. The deposition potential was optimized in the range of -0.7 to $0.7 \mathrm{~V}$.
The highest stripping signal was observed at $E_{\text {acc }}=$ $-0.5 \mathrm{~V}$ and $t_{\mathrm{acc}}=60 \mathrm{~s}$ (Figs. 8B and 8C).
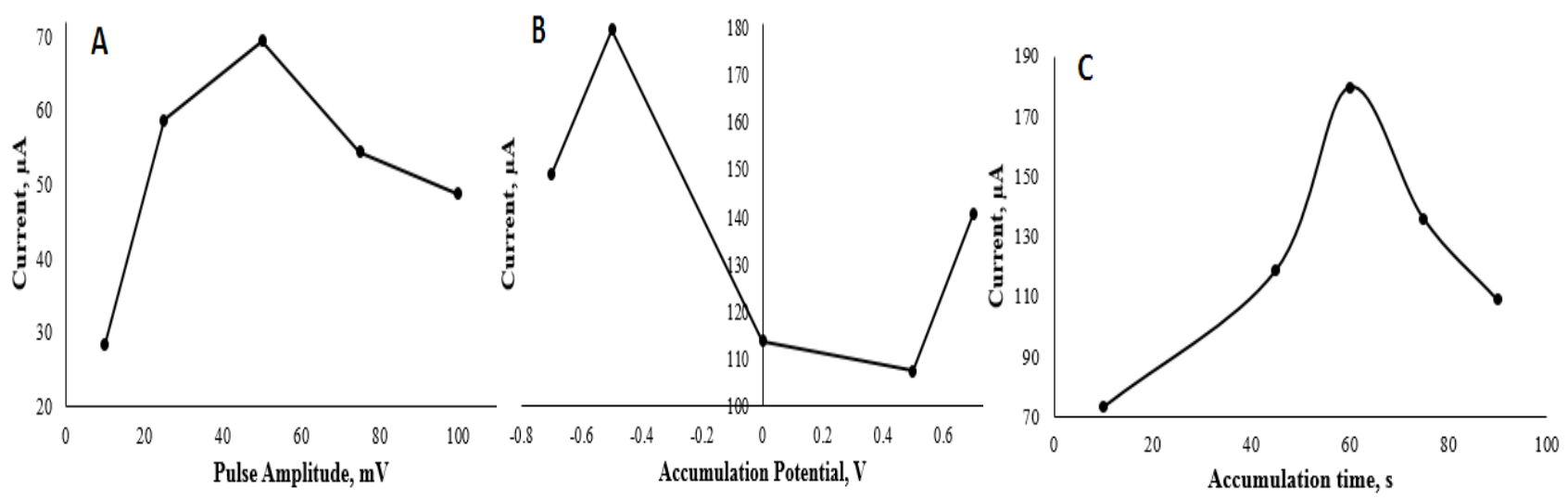

Fig. 8. SWV parameter effects: amplitude $(\mathbf{A})$, accumulation potential $\left(E_{\text {acc }} ; \mathbf{B}\right)$, and accumulation time ( $\left.\mathrm{t}_{\text {acc }} ; \mathbf{C}\right)$

\subsection{Resveratrol detection}

In order to check the affinity of the poly(Lphenylalanine) gold electrode toward RESV, SWV measurements were employed in 0.1 M PBS buffer at $\mathrm{pH}=1.2$.
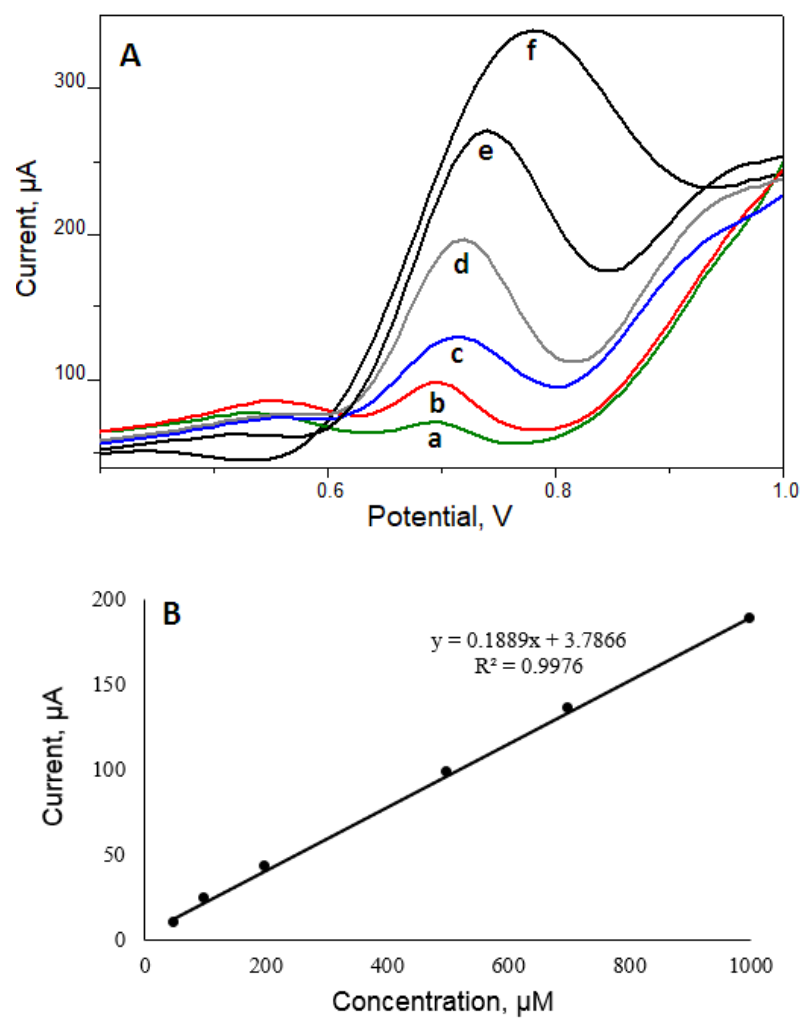

Fig. 9. Anodic SWVs (A) and calibration graph (B) of RESV (a: 50 , b: 100 , c: 200 , d: 500 , e: 700 , f: $1000 \mu \mathrm{M})$ in PBS $(0.1$ $\mathrm{M}), \mathrm{pH}=1.2$. Accumulation time $60 \mathrm{~s}$, accumulation potential $-0.5 \mathrm{~V}$, amplitude $50 \mathrm{mV}$, and frequency $70 \mathrm{~Hz}$.
SWVs were registered at different RESV solution concentrations under the optimum conditions studied above. An increase in current peak intensity was noticed with increasing RESV concentration (Fig. 9A). This is explained by the oxidation of RESV under the modified electrode. To evaluate the selectivity of the modified electrode, we plotted the variation of current $(\mu \mathrm{A})$ as a function of RESV concentration (Fig. 9B).

The features of the modified gold electrode, as well as linear ranges, detection limit, and quantitation limit are summarized in Table 1. A linear dependence of the current response is obtained $\left(R^{2}=0.9976\right)$ in a concentration range of 50 to $1000 \mu \mathrm{M}$ with the modified electrode with a sensitivity of $0.2 \mu \mathrm{A} / \mu \mathrm{M}$.

Table 1

Analytical performance of the modified electrode obtained by $S W V$

\begin{tabular}{cc}
\hline \hline Matrix & Poly(L-phenylalanine)/Gold E \\
\hline Sensibility $(\mu \mathrm{A} / \mu \mathrm{M})$ & 0.2 \\
Domain of linearity $(\mu \mathrm{M})$ & $50-1000$ \\
Detection limit $(\mu \mathrm{M})$ & 35.16 \\
\hline \hline
\end{tabular}

The reproducibility of measurements using the poly(L-phenylalanine) gold electrode under the same conditions and same RESV concentration was studied. Repeated measurements demonstrated similar voltammograms, and it proved the reproducibility of our modified electrode. 
Figure 10 shows the reproducibility and stability of SWV responses for $500 \mu \mathrm{M}$ RESV in 0.1 $\mathrm{M}$ PBS, pH 1.2, using 15 different poly(Lphenylalanine)-modified gold electrodes, each per-

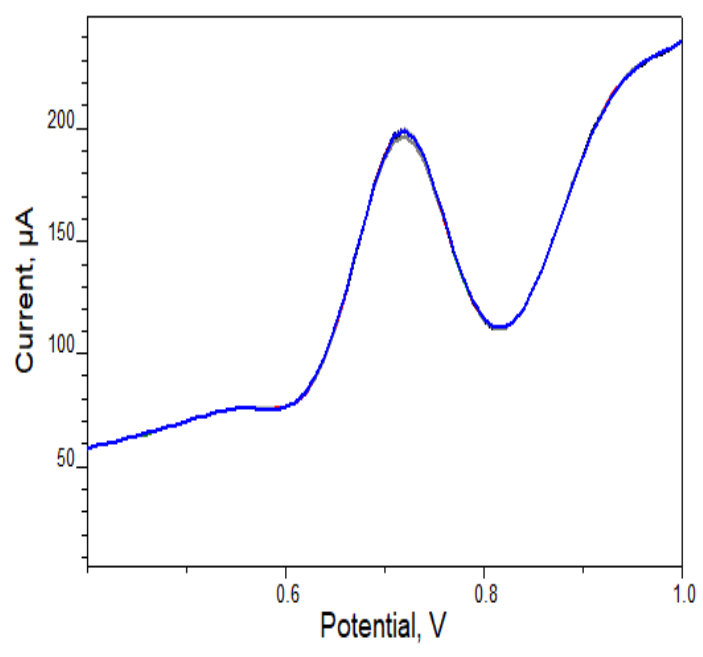

formed with three measurements. Using these measurements results, standard deviation was calculated as 0.92 , RSD \% 0.93 , and stability as 99.07.

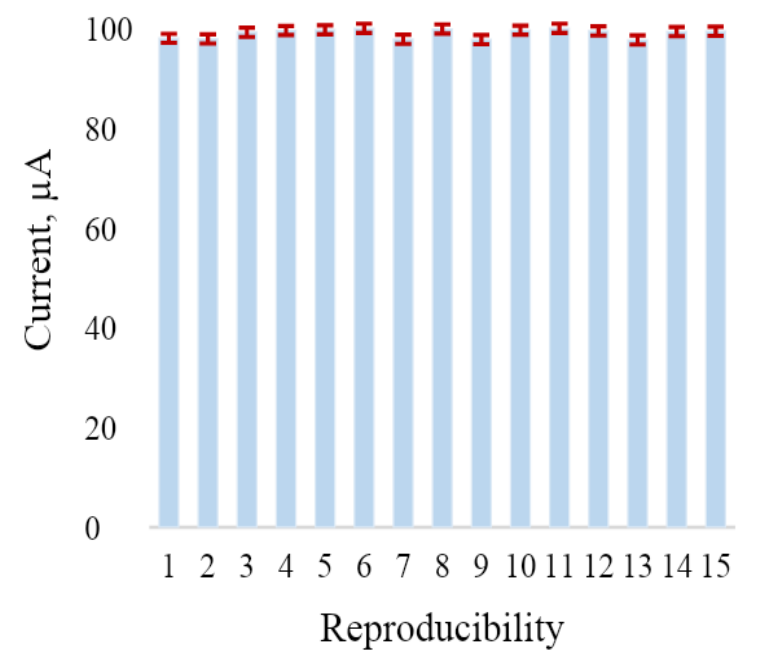

Fig. 10. Reproducibility of the SWV responses and error bars of $500 \mu \mathrm{M}$ RESV on the poly(L-phenylalanine)-modified gold electrode in 0.1 M PBS, $\mathrm{pH}=1.2(n=15)$.

\subsubsection{Determination of RESV in a red wine sample}

A red wine sample was used to examine the applicability of the method developed for RESV determination in real samples. The poly(Lphenylalanine) gold electrode was employed for quantification of RESV in a red wine sample. In order to study the recovery, we added a known amount of RESV into the red wine sample, as depicted in Table 2. According to the results obtained in red wine samples, the developed modified electrode clearly could be employed in real sample analysis (Table 2).

\section{Table 2}

Determination of RESV in red wine samples

\begin{tabular}{ccc}
\hline \hline Added & Found $(\boldsymbol{\mu M})$ & Recovery \% \\
\hline $50 \mu \mathrm{M}$ & 52.75 & 105.50 \\
$100 \mu \mathrm{M}$ & 102.84 & 102.84 \\
\hline \hline
\end{tabular}

The research method presented here was carried out using simple, selective, sensitive, low cost, and easily-prepared gold working electrodes that require only a short analysis time to determine RESV using poly(L-phenylalanine). There is interest in the deposition of RESV with a fast and easily-prepared poly(L-phenylalanine) gold electrode in PBS buffer $(\mathrm{pH}=1.2)$. The optimum conditions for determination of RESV were as follows: PBS buffer $(\mathrm{pH}=1.2),-0.5 \mathrm{~V}$ accumulation potential, accumulation time of $60 \mathrm{~s}$, and pulse amplitude of $50 \mathrm{mV}$. The developed sensor showed, under optimum conditions, sensitivity and selectivity towards RESV with linearity in the range of 50 to $1000 \mu \mathrm{M}$. The quantitation and detection limits were 35.15 and $105.5 \mu \mathrm{M}$, respectively, after a $60 \mathrm{~s}$ accumulation time. Furthermore, the applicability of the proposed electrode in red wine samples gives promising results.

\section{CONCLUSIONS}

In this study, the electrochemical polymerization of L-phenylalanine in an aqueous solution was performed. The effect of electrochemical parameters on the sensing ability of the electrode towards RESV was studied. The modified electrode exhibited good sensitivity to RESV with a large linear range. The results found with the poly(L-phenylalanine) gold electrode were reproducible with fifteen other measurements, under the same conditions.

\section{REFERENCES}

[1] H. K. Biesalski, Polyphenols and inflammation: Basic interactions, Curr. Opin. Clin. Nutr. Metab. Care, 10 (6), 724-728 (2007). DOI: 10.1097/MCO.0b013e3282f0cef2

[2] L. J. Laslett, Jr. P. Alagona, B. A. Clark 3rd, Jr.J. P. Drozda, F. Saldivar, S. R. Wilson, C. Poe, M. Hart, The worldwide environment of cardiovascular disease: Preva- 
lence, diagnosis, therapy, and policy issues: A report from the American College of Cardiology, J. Am. Coll. Cardiol., 60, 1-49 (2012). DOI: 10.1016/j.jacc.2012.11.002

[3] A. Abdulla, X. Zhao, F. Yang, Natural Polyphenols Inhibit Lysine-Specific Demethylase-1, Journal of Biochemical and Pharmacological Research, 1 (1), 56-63 (2013).

[4] M. Shakibaei, K. B. Harikumar, B. B. Aggarwal, Resveratrol addiction: to die or not to die, Molecular Nutrition \& Food Research, 53, 115-128 (2009). DOI: $10.1002 / \mathrm{mnfr} .200800148$

[5] W. Yu, Y. C. Fu, W. Wang, Cellular and molecular effects of resveratrol in health and disease, Journal of Cellular Biochemistry, 113 (3), 752-759 (2012). DOI: $10.1002 /$ jcb.23431

[6] J. M. Smoliga, J. A. Baur, H. A. Hausenblas, Resveratrol and health - A comprehensive review of human clinical trials, Mol. Nutr. Food Res., 5 (8), 1129-1141 (2011). DOI: $10.1002 / \mathrm{mnfr} .201100143$

[7] J. A. Baur, D. A. Sinclair, Therapeutic potential of resveratrol: the in vivo evidence. Nat. Rev. Drug Discovery, 5, 493-506 (2006). DOI:10.1038/nrd2060

[8] S. M. Mugo, B. J. Edmunds, D. J. Berg, N. K. Gill, An integrated carbon entrapped molecularly imprinted polymer (MIP) electrode for voltammetric detection of resveratrol in wine, Anal. Methods, 7, 9092-9099 (2015). DOI:10.1039/C5AY01799H

[9] X. Huang, G. Mazza, Simultaneous analysis of serotonin, melatonin, piceid and resveratrol in fruits using liquid chromatography tandem mass spectrometry, Journal of Chromatography A, 1218 (24), 3890-3899 (2011).

[10] E. Kuyumcu Savan, Square Wave Voltammetric (SWV) Determination of Quercetin in Tea Samples at a SingleWalled Carbon Nanotube (SWCNT) Modified Glassy Carbon Electrode (GCE), Anal. Lett., 53 (6), 858-872 (2020). DOI: 10.1080/00032719.2019.1684514

[11] S. Tahtaisleyen, O. Gorduk, Y. Sahin, Electrochemical determination of tartrazine using a graphene/poly(Lphenylalanine) modified pencil graphite electrode, Anal. Lett., 53 (11), 1683-1703 (2020).

DOI: $10.1080 / 00032719.2020 .1716242$

[12] Ö. Güngör, İ. Özcan, M. A. Erdoğan, B. Ateş, S. Köytepe, Differential pulse voltammetric (CPV) determination of the anesthetic bupivacaine using polyimide membrane-based electrodes, Anal. Lett., 53 (2), 228-244 (2020). DOI: 10.1080/00032719.2019.1646752

[13] Y. Altun, B. Uslu, S. A. Ozkan, Electroanalytical characteristics of Lercanidipine and its voltammetric determination in pharmaceuticals and human serum on boron-doped diamond electrode, Anal. Lett., 43 (12), 1958-1975 (2010). DOI:10.1080/00032711003687047

[14] G. Ziyatdinova, E. Kozlova, H. Budnikov, Chronocoulometry of wine on multi-walled carbon nanotube modified electrode: Antioxidant capacity assay, Food Chemistry, 196, 405-410 (2016).

DOI: 10.1016/j.foodchem.2015.09.075.
[15] Y. Zhou, L. Tang, G. Zeng, C. Zhang, Y. Zhang, X. Xie, Current progress in biosensors for heavy metal ions based on DNAzymes/DNA molecules functionalized nanostructures: A review, Sensor. Actuat. B-Chem., 223, 280-294 (2016). DOI: 10.1016/j.snb.2015.09.090

[16] L. Gao, Q. Chu, J. Ye, Determination of transResveratrol in wines, herbs and health food by capillary electrophoresis with electrochemical detection, Food Chem., 78 (2), 255-260 (2002). DOI: $10.1016 / \mathrm{s} 0308-8146(02) 00115-2$

[17] J. X. Liu, Y. J. Wu, F. Wang, L. Gao, and B. X. Ye, Adsorptive voltammetric behaviors of resveratrol at graphite electrode and its determination in tablet dosage form, Journal of the Chinese Chemical Society, 55, 264 (2008). DOI:10.1002/jccs.200800039

[18] B. Pekec, A. Oberreiter, S. Hauser, K. Kalcher, A. Ortner, Electrochemical sensor based on a cyclodextrin modified carbon paste electrode for trans-resveratrol analysis, Int. J. Electrochem. Sci., 7, 4089-4098 (2012).

[19] O. Corduneanu, P Janeiro, A. M. O. Brett, On the electrochemical oxidation of resveratrol, Electroanalysis, 18 (8), 757-762 (2006).

[20] D. Airado-Rodríguez, T. Galeano-Díaz, I. Durán-Merás, Determination of trans-resveratrol in red wine by adsorptive stripping square-wave voltammetry with medium exchange, Food Chem., 122 (4), 1320-1326 (2010). DOI: $10.1016 /$ j.foodchem.2010.03.098

[21] H. Zhang, L. Xu, J. Zheng, Anodic voltammetric behavior of resveratrol and its electroanalytical determination in pharmaceutical dosage form and urine, Talanta, 71 (1), 19-24 (2007). DOI: 10.1016/j.talanta.2006.03.017

[22] X. Ma, M. Chao, Electrocatalytic determination of maltol in food products by cyclic voltammetry with a poly(L-phenylalanine) modified electrode, Anal. Methods, 5 (20), 5823-5829 (2013).

[23] L. Wang, P. Huang, J. Bai, H. Wang, L. Zhang, Y. Zhao, Simultaneous electrochemical determination of phenol isomers in binary mixtures at a poly (phenylalanine) modified glassy carbon electrode, Int. J. Electrochem. Sci., 1, 403-413 (2006).

[24] R. S. Deinhammer, M. Ho, J. W. Anderegg, M. D. Porter, Electrochemical oxidation of amine-containing compounds: a route to the surface modification of glassy carbon electrodes, Langmuir, 10 (4), 1306-1313 (1994). DOI: 10.1021/la00016a054

[25] D. Guziejewski, Square-wave amplitude effect in cathodic and anodic stripping square-wave voltammetry, Electroanalysis, 31, 231-238 (2019). DOI: 10.1002/elan.201800425

[26] V. Mirceski, R. Gulaboski, Recent achievements in square-wave voltammetry (a review), Maced. J. Chem. Chem. Eng., 33 (1), 1-12 (2014). DOI: http://dx.doi.org/10.20450/mjcce.2014.515

[27] V. Mirceski, R. Gulaboski, M. Lovric, I. Bogeski, R. Kappl, M. Hoth, Square-wave voltammetry: a review on the recent progress, Electroanalysis, 25 2411-2422 (2013). DOI: 10.1002/elan.201300369 